\title{
Relationship of Students' Activities, Responses, and Cognitive Learning Outcomes on Natural Science Learning-Based Ethno-STEM in Secondary School
}

\author{
*Septi Budi Sartika, Nur Efendi, Fitria Eka Wulandari \\ Natural Science Education Programs, Faculty of Educational Science adn Psychology, \\ Universitas Muhammadiyah Sidoarjo, Jalan Mojopahit 666 B Sidoarjo Jawa Timur, 61215 \\ Indonesia
}

*Corresponding Author e-mail: septibudi1@umsida.ac.id

Received: December 2021; Revised: January 2022; Published: January 2022

\begin{abstract}
The research aims to describe the relationship of students' activities, responses, and cognitive learning outcomes in natural science learning based ethno-STEM in secondary school. Research methods use quantitative approaches with this type of correlation research. The population and research sample are class VIII students at SMP Muhammadiyah 5 Tulangan Sidoarjo. Data collection techniques use questionnaires and documentation. Questionnaires are used to determine students' activities and responses during natural science learning based ethno-STEM. Documentation in the form of documented student learning test results. In the study results test used cognitive learning results that refer to Bloom's C4 taxonomy, namely analytical thinking skills. Data analysis techniques use descriptive statistics that use SPSS-assisted product-moment correlation tests. The results showed that in the implementation of natural science learning based ethno-STEM there was a weak relationship between: 1) there is an activity relationship to students' cognitive learning outcomes with a contribution of $0.2 \%, 2$ ) there is a response relationship to student cognitive learning outcomes with a contribution of $0.9 \%$, and 3) there is a relationship of activity and response to student cognitive learning outcomes with a contribution of $1 \%$. There are allegations that other variables also affect students' cognitive learning outcomes, these variables need to be revealed through further.
\end{abstract}

Keywords: activities, response, learning outcome, natural science learning, secondary school

How to Cite: Sartika, S., Efendi, N., \& Wulandari, F. (2022). Relationship of Students' Activities, Responses, and Cognitive Learning Outcomes on Natural Science Learning-Based Ethno-STEM in Secondary School. Prisma Sains : Jurnal Pengkajian Ilmu dan Pembelajaran Matematika dan IPA IKIP Mataram, 10(1), 84-92. doi:https://doi.org/10.33394/j-ps.v10i1.4655

https://doi.org/10.33394/j-ps.v10i1.4655

Copyright $\odot$ 2022, Sartika et al This is an open-access article under the CC-BY License.

\section{INTRODUCTION}

Learning outcomes are summarized as the maximum results obtained by students after the learning process with certain teaching materials. One aspect of learning outcomes is cognitive learning outcomes. Cognitive learning outcomes are expressed through scores from test results as indicators students can conceptualize something from the material studied (Susanto, 2014), which is used to describe students' success rates in a learning. Mudjiono (2013) describes that cognitive learning outcomes are generally often used as a leading indicator of student succes. In contrast, affective and psychomotor aspects must also be taken into account as learning outcomes. These cognitive learning outcomes are modified into various thinking skills while also being $21^{\text {st }}$ Century skills.

The demands of skill achievement in the $21^{\text {st }}$ century are very much, including students can communicate writing and oral, cooperation skills, thinking skills, creativity, research skills, and problem-solving skills. These skills are done to be able to compete and grow in the future. These skills students learn through classroom teaching and learning activities and 
implementing them in everyday life. According to Sumantri et al (2019), skills needed in the $21^{\text {st }}$ Century, include: 1) learning innovation skills, 2) information, median and technology skills, 3) life and carrer skills. According to Rozi and Hanum (2019), $21^{\text {st }}$ century learning is simply interpreted as learning that provides $21^{\text {st }}$ century skills to learners, namely $4 \mathrm{C}$ which includes: (1) Communication (2) Collaboration, (3) Critical Thinking and problem solving, and (4) Creative and Innovative. Thus the role of student activities is quite important in this regard.

Student activity is defined as all activities carried out by teachers during the learning process that produce a behavior that affects student learning outcomes. Pradani et al (2018) show that students' verbal activity is dominated by answering sentences as much as $69.44 \%$ and hands-on activity is $33.12 \%$. This data shows that teachers ask a lot of questions, and students answer a lot of questions from teachers, while for activities, students work less than other activities. This certainly needs to change, and it just requires regular and structured habituation. These student activities are generally associated with the student's response during learning.

Student response is behavior that arises due to stimulation or stimulus by the teacher in response to something that has been learned. The student's response during the learning process is generally related to the student's activities in the classroom. Both affect students' learning outcomes. Arini and Lovisa (2019) shows that student response will be high if teachers use interesting learning media based on the surrounding environment. Student response will be high when applying the appropriate learning model (Faradisya Ekapti, 2016). The student's response followed the treatment given by the teacher to the student during the learning process.

Natural Sciences is one of the subjects studied in school. There is a sharing of learning media and learning strategies to teach natural science. One such learning strategy is natural science learning with ethno-STEM. Learning that makes local wisdom a model in understanding natural science concepts integrated into the stem (Scientific, Technology, Engineering, Mathematics) integrated curriculum. Reffiane et al (2021) explained the application of Ethno-STEM approach to students that is done comprehensively can be implemented properly through the online learning process. Natural science learning with ethno-STEM can not only be done offline, but online is also carried out properly.

Observation results at SMP Muhammadiyah 5 Tulangan Sidoarjo, showed that ethnoSTEM learning has been applied and obtained good results judging from student learning outcomes. In the learning process, teachers are based on project-based learning models that are integrated ethno-STEM, namely local wisdom Sidoarjo and STEM curriculum on respiratory system materials in humans. Students are given modeling on the geographical location of sidoarjo communities divided into communities living in pond areas, industrial areas, and rice fields. Students are given activities to create the design of human breathing apparatus with the aim to be able to answer whether the lung capacity of the community will be the same or what. With these student-based activities, learning becomes fun, learning is done offline and online due to the impact of the covid-19 pandemic.

Priyani and Nawawi (2020), Ethno-STEM learning assisted by simple digital microscopes can improve students' Process Science Skills. Sumarni and Kadarwati (2020) stated that project-based learning integrated with ethno-STEM can improve high-level thinking skills. Thus it can be stated that natural science learning with ethno-STEM can affect natural science learning outcomes. Students' activities and responses influence IPA learning outcomes. Muchtadi, et al (2017) found student learning activities contribute to student learning outcomes and student responses contribute to student learning outcomes after genius learning is applied. Furthermore, Rahmalia (2021) found student responses have a significant relationship with cognitive learning outcomes.

Factors that influence learning outcomes according to Slameto (2010), are generally grouped into internal factors and external factors. The internal factors in question are factors 
that come from within the learners that include physiological (physical) and psychological factors. External factors are factors that come from outside the student, namely school, family, and community factors. Purwanto expained, these school factors can be divided into curriculum, teacher, facilities and facilities, and administration or management (Purwanto, 2014). Natural science learning based Ethno-STEM is carried out well in the classroom because there is curriculum support, teachers, facilities and facilities, as well as administras / management education. Student activity and response is one of the factors that arise from within learners, namely psychological factors. Psychological factors that influence learning outcomes include intelligence, attention, interest, talent, motives, maturity, and readiness. Student activities in learning are included in the form of readiness, while the student's response is included in the form of attention. This research will uncover the relationship between student activity, student response, and students' cognitive learning outcomes in natural science based ethno-STEM in secondary school.

\section{METHOD}

This type of research uses quantitative research type correlation, which is expose facto research that uncovers facts that have occurred. Fraenkel et al. (2012) explained that "In associational research, the relationship among two or more variables are studied without any attempt to influence them." From the statement is that correlation or correlational research is an attempt is made to find out if there is a connection between ariables from one to another. The variables in the study include student activity as variable $\mathrm{X}_{1}$, student response as variable $\mathrm{X}_{2}$, and cognitive learning outcomes as variable $\mathrm{Y}$. Population and sample researchare students of class VIII at SMP Muhammadiyah 5 Tulangan Sidoarjo, as many as 30 students. Research instruments use student activity questionnaires, student response questionnaires, and documentation of students' cognitive learning outcomes. Questionnaire uses the Likert scale which is then converted to the numbers 0-100. Data retrieval techniques use questionnaires of students' perceptions of activity and responses in ethno-STEM-based learning and evaluation documentation in the form of value of students' cognitive learning outcomes, namely analytical thinking skills. Questionnaires on student activity perception and response are given to students who have undertaken learning based ethno-STEM. Data analysis techniques use inferential statistics through SPSS-assisted product moment correlation tests, with the prerequisite of normal and homogeneous distributed samples.

\section{RESULTS AND DISCUSSION}

The results showed an interpretation of student activity, cognitive learning outcomes, and student response on a scale of 0-100. The following are presented data on student activity $\left(\mathrm{X}_{1}\right)$, student response $\left(\mathrm{X}_{2}\right)$, and student cognitive learning outcomes $(\mathrm{Y})$ :

Table 1. Student Activity Scores in Natural Science Learning based Ethno-STEM

\begin{tabular}{cc}
\hline Score Range & Percentage $(\boldsymbol{\%})$ Number of Students \\
\hline $65-69$ & 16.7 \\
$70-74$ & 23.3 \\
$75-79$ & 16.7 \\
$80-84$ & 30.0 \\
$85-89$ & 10.0 \\
$90-94$ & 0.3 \\
\hline
\end{tabular}

Based on Table 1, it is obtained that the highest score for student activity is $80-84$. Aspects observed in student activity include understanding learning objectives, ethno-STEM strategies, project-based learning, and active learning. Student activity is said to be good, this is in accordance with Wibowo (2016), learning is said to be successful and quality if all or at least most (75\%) students are actively involved in the learning process. The student activity score is based on the following indicators. 
Table 2. Student Activities Based on Student Perceptions

\begin{tabular}{|c|c|c|c|c|c|c|c|}
\hline \multirow{3}{*}{ Aspect } & \multicolumn{4}{|c|}{ Meeting to } & \multirow{3}{*}{$\overline{\boldsymbol{P}}$} & \multirow{3}{*}{$\begin{array}{l}\text { Koef. } \\
\text { R }(\%)\end{array}$} & \multirow{3}{*}{ Information } \\
\hline & \multicolumn{2}{|c|}{1} & \multicolumn{2}{|c|}{2} & & & \\
\hline & $\%$ & $\begin{array}{l}\text { Koef. } \\
\text { R }(\%)\end{array}$ & $\%$ & $\begin{array}{c}\text { Koef.R } \\
(\%)\end{array}$ & & & \\
\hline $\begin{array}{l}\text { Understand the purpose } \\
\text { of learning }\end{array}$ & 79.69 & 96.23 & 76.04 & 90.12 & 77.87 & 93.18 & $\mathrm{R}$ \\
\hline $\begin{array}{l}\text { Understanding ethno- } \\
\text { STEM strategies }\end{array}$ & 75.00 & 90.57 & 84.38 & 100.00 & 79.69 & 95.29 & $\mathrm{R}$ \\
\hline $\begin{array}{l}\text { Understand project- } \\
\text { based learning }\end{array}$ & 75.00 & 90.57 & 72.92 & 86.42 & 73.96 & 88.50 & $\mathrm{R}$ \\
\hline Active in learning & 79.69 & 96.23 & 80.21 & 95.06 & 79.95 & 87.65 & $\mathrm{R}$ \\
\hline
\end{tabular}

Based on Table 2, it is obtained that the aspect of understanding ethno-STEM strategies is highest among other aspects. According to Parasamya and Wahyuni (2017), the activities of teachers and students are said to be good when they get results of at least $75 \%$. Conversely, if the results obtained below 75\%, then teachers and students' activities are said to be less or bad. The results of Yanni (2018), the application of STEM education-based TAPPS strategies in learning process activities train students to play an active and skilled role in solving problems in pairs in one group by first drawing up settlement steps and increasing students' mastery of learning materials.

Table 3. Student Response Scores in Natural Science Learning based Ethno-STEM

\begin{tabular}{lcc}
\hline Score Range & Persentage (\%) Number of Student \\
\hline $75-78$ & 13.3 \\
$79-82$ & 33.3 \\
$83-86$ & 16.7 \\
$87-90$ & 30.0 \\
$91-94$ & 0.3 \\
$95-98$ & 0.3 \\
\hline
\end{tabular}

Based on Table 3, student response indicators include student responses regarding learning devices used, ethno-STEM strategies, increased analytical thinking, problem-solving processes, active teachers in learning, students active in learning, and increasing selfconfidence. According to Hermawan et al (2021), students' response is good if it is in the range of $61-80 \%$. In studies that have been done student responses can be categorized as good because they are between 75-98. The student's response is based on the following indicators:

Table 4. Student Response Based on Indicators

\begin{tabular}{|c|c|c|c|}
\hline Number & Indicator & Statement & Response \\
\hline \multirow[t]{5}{*}{1} & Learning & There is syllabus. & Yes, $100 \%$ \\
\hline & devices used & There is lesson plan. & Yes, $85 \%$ \\
\hline & & $\begin{array}{l}\text { The existence of teaching materials either } \\
\text { in the form of ppt, pdf, or video. }\end{array}$ & Yes, $90 \%$ \\
\hline & & The learning device used... & New, $100 \%$ \\
\hline & & The learning device used... & Easy, $100 \%$ \\
\hline \multirow[t]{2}{*}{2} & $\begin{array}{l}\text { Ethno-STEM } \\
\text { Strategy }\end{array}$ & $\begin{array}{l}\text { Natural science learning based Ethno- } \\
\text { STEM. }\end{array}$ & New, $100 \%$ \\
\hline & & $\begin{array}{l}\text { Learn natural science with local wisdom } \\
\text { Sidoarjo. }\end{array}$ & Fun, $75 \%$ \\
\hline \multirow[t]{2}{*}{3} & $\begin{array}{l}\text { An increase } \\
\text { in analytical }\end{array}$ & What analytical thinking skills are? & $\begin{array}{l}\text { Understand, } \\
50 \%\end{array}$ \\
\hline & thinking skills & Analytical thinking skills are increasing. & Increase, $75 \%$ \\
\hline 4 & $\begin{array}{l}\text { There is a } \\
\text { problem- }\end{array}$ & What is the ability to solve the problem? & $\begin{array}{l}\text { Understand, } \\
75 \%\end{array}$ \\
\hline
\end{tabular}




\begin{tabular}{|c|c|c|c|c|}
\hline \multirow{3}{*}{$\begin{array}{c}\text { Number } \\
5\end{array}$} & \multirow{4}{*}{\begin{tabular}{l}
\multicolumn{1}{c}{ Indicator } \\
solving \\
process \\
The teacher is \\
active during \\
learning.
\end{tabular}} & \multirow{2}{*}{$\frac{\text { Statement }}{\text { erstand the problem-solving }}$} & \multicolumn{2}{|c|}{ Response } \\
\hline & & & Yes, 7 & \\
\hline & & $\begin{array}{l}\text { The teacher guides students in completing } \\
\text { the project }\end{array}$ & $\begin{array}{l}\text { Very } \\
75 \%\end{array}$ & Agree, \\
\hline & & $\begin{array}{l}\text { The teacher answers the student's questions } \\
\text { when asked questions / provides feedback }\end{array}$ & $\begin{array}{l}\text { Very } \\
80 \%\end{array}$ & Agree, \\
\hline 6 & $\begin{array}{l}\text { Students are } \\
\text { active during }\end{array}$ & Students are present in the learning. & $\begin{array}{l}\mathrm{Be} \\
100 \%\end{array}$ & present, \\
\hline & learning. & $\begin{array}{l}\text { Students are active in discussion and } \\
\text { project completion }\end{array}$ & $\begin{array}{l}\text { Very } \\
85 \%\end{array}$ & Active, \\
\hline 7 & $\begin{array}{l}\text { Increases self- } \\
\text { confidence }\end{array}$ & $\begin{array}{l}\text { Students are increasingly confident in } \\
\text { learning. }\end{array}$ & $\begin{array}{l}\text { Very } \\
75 \%\end{array}$ & Agree \\
\hline & & Students are able to communicate well. & $\begin{array}{l}\text { Very } \\
75 \%\end{array}$ & Agree, \\
\hline
\end{tabular}

Based on Table 4, that the student's response to ethno-STEM learning is quite positive, this is evidenced by an average of $75 \%$ of students giving a positive response to learning activities. This is like the results of Aninda, et al (2020), most students give positive responses to project-based learning models, they feel happy, satisfied and increase motivation in learning. Muthmainah (2019), student response to STEM approaches obtained that $86.36 \%$ of students agreed to the application of STEM approaches to comparative materials, particularly making floor plans.

The student's learning outcomes measured were cognitive learning outcomes. These cognitive learning outcomes use cognitive problems that measure analytical thinking, which refers to bloom taxonomy level 4 or C4. According to Sartika (2017), analytical skills as a high level of cognitive ability will be possessed by students if previously students had the ability to know, understand, and apply. Here are presented students' cognitive learning outcomes in learning based ethno-STEM.

Table 5. Students' Cognitive Learning Outcomes in Natural Science Learning based EthnoSTEM

\begin{tabular}{ccc}
\hline Score Range & Persentage (\%) Number of Student & Information \\
\hline $65-69$ & 10.0 & Not Complete \\
$70-74$ & 23.3 & Complete \\
$75-79$ & 26.7 & Complete \\
$80-84$ & 30.0 & Complete \\
$85-89$ & 10.0 & Complete \\
\hline
\end{tabular}

Based on Table 5, 10\% of students are unfinished in cognitive learning outcomes. However, classically, students' cognitive learning outcomes can be said to be complete. According to Mulyasa (2012), the completion of learning outcomes classically when at least $85 \%$ of all students get a minimum score. This is in accordance with the results of Herak (2021), the average learning outcome of learners increased by 34.16 with STEM models from 54.52 to 88.68 . Nasrah (2021), classically $83.87 \%$ met the minimum completion criteria and $16.13 \%$ did not achieve minimum completion.

Indicators of cognitive learning outcomes are that students are able to think analysis that is distinguishing, organizing, and attributing. The following will be presented students' cognitive learning outcomes based on indicators.

Table 6. Students' Cognitive Learning Outcomes Based on Analytical Thinking Indicators

\begin{tabular}{lll}
\hline Indicator & N-gain & Information \\
\hline Differentiating & 0.62 & Moderate \\
Organizing & 0.64 & Moderate \\
Atributting & 0.46 & Moderate \\
\hline
\end{tabular}


Based on Table 4, it was obtained that cognitive learning outcomes based on indicators thinking analysis had moderate improvement scores across all indicators. The results of this improvement can be categorized well in the achievement of student learning outcomes. The results of Sartika, et al (2020), the average value of analytical thinking skills can be said to increase with a high category of 78.9 from 51.68 with the average indicator attributing the lowest among other indicators and actually down in its post-test value. This is because attributing is the ability to label something, a label is given if one is able to understand accurate and relevant phenomena and information. The results also showed that the indicator attributes the lowest in other indicators, but still has the same moderate improvement category.

If the correlation test of the three variables, namely student activity $\left(\mathrm{X}_{1}\right)$, student response $\left(\mathrm{X}_{2}\right)$, and student cognitive learning outcomes $(\mathrm{Y})$, will be obtained the following results.

Table 7. Correlation between Student Activity $\left(\mathrm{X}_{1}\right)$ and Student Cognitive Learning Outcomes (Y)

\begin{tabular}{lllll}
\hline Model & $\mathrm{R}$ & $\mathrm{R}$ Square & Adjusted R Square & Std. Error of the Estimate \\
\hline 1 & $.045^{\mathrm{a}}$ & .002 & -.034 & 5.291 \\
a. Predictors: (Constant), student's activities & \\
\hline
\end{tabular}

Based on Tabel 7, correlation values range from -1.00 to 1.00 . The magnitude of the correlation between student activity variables and student cognitive learning outcomes is 0.045 indicates that the correlation between student activity and student cognitive learning outcomes is very small (weak). The value of activity contribution to student cognitive learning outcomes by $0.2 \%$, meaning that the contribution of student activity to cognitive learning outcomes is relatively small. Thus it can be said that student activity is not the only variable that also affects students' cognitive learning outcomes. This low correlation also indicates that there are other variables that also affect students' cognitive learning outcomes. Nuraini, et al (Jurnal Ilmiah et al., 2018), there is an influence between student learning activities and student outcomes on chemistry subjects. Harahap (Harahap et al., 2014), there is a significant relationship between motivation and student learning activities to students' cognitive learning outcomes with STAD-type cooperative learning in ecosystem materials.

Table 8. Correlation Between Student Response and Student Cognitive Learning Outcomes

\begin{tabular}{lllll}
\hline Model & R & R Square & Adjusted R Square & Std. Error of the Estimate \\
\hline 1 & $.094^{\mathrm{a}}$ & .009 & -.027 & 5.273
\end{tabular}

a. Predictors: (Constant), Student's Response

Based on Tabel 8, correlation values range from -1.00 to 1.00 . The magnitude of the correlation between student response variables and students' cognitive learning outcomes is 0.094 indicates that the correlation between student response and student cognitive learning outcomes is very small (weak). The contribution value of student response to student cognitive learning outcomes by $0.9 \%$ means that the contribution of student response to student cognitive learning outcomes is quite small. Thus it can be stated that student responses and cognitive learning outcomes are not related to each other. This is evidenced by weak correlation test results and hypothesis test results for which there is no relationship between the two variables. The results of the Rahmalia (Rahmalia, 2021), showed there was a relationship between students' response to parental religious guidance at home and students' cognitive learning outcomes in Islamic subjects. This is likely due to the positive student response that helps build student reasoning so that students learn better.

Table 9. Correlation of Student Activity $\left(\mathrm{X}_{1}\right)$ and Student Response $\left(\mathrm{X}_{2}\right)$ with Student Cognitive Learning Outcomes

\begin{tabular}{|c|c|c|c|c|}
\hline Model & $\mathrm{R}$ & R Square & Adjusted R Square & Std. Error of the Estimate \\
\hline 1 & $.099^{\mathrm{a}}$ & .010 & -.064 & 5.367 \\
\hline
\end{tabular}


Based on Table 9, correlation values range from -1.00 to 1.00 . The magnitude of the correlation between student activity variables and student response with student cognitive learning outcomes is 0.099 , suggesting that the correlation between student activity and student response with student cognitive learning outcomes is very small (weak). The contribution value of student activity and student response to large results by $1 \%$, is quite small. Thus it can be stated that the 2 variables given, namely student activity and student response are not variables that also affect students' cognitive learning outcomes, although the results state that student activity is good category and positive student response to learning and cognitive learning outcomes that achieve completion. However, the results of Muchtadi, et al (Muchtadi et al., 2017), there is a meaningful relationship between learning activities and student responses to student learning outcomes. The results showed both variables, namely activity and response contributed to learning outcomes.

\section{CONCLUSION}

Based on the results of research and discussion, it can be concluded in the implementation of natural science learning based ethno-STEM: 1) there is an activity relationship to students' cognitive learning outcomes with a contribution of $0.2 \%, 2$ ) there is a response relationship to student cognitive learning outcomes with a contribution of $0.9 \%$, and 3 ) there is a relationship of activity and response to student cognitive learning outcomes with a contribution of $1 \%$. There are allegations that other variables also affect students' cognitive learning outcomes, these variables need to be revealed through further

\section{RECOMMENDATION}

Research only uncovers a large relationship between students' activity, response, and cognitive learning outcomes in natural science learning based ethno-STEM. The relationship of the three can be non-permanent due to the process of retrieving data at the time of the covid-19 pandemic with all limitations. Further research is expected to uncover variables that contribute to students' cognitive learning outcomes, of course with the wider population.

\section{ACKNOWLEDGMENT}

The author thanked all the citizens of SMP Muhammadiyah 5 Tulangan Sidoarjo, especially the Principal and natural science teacher, who had deigned to be used as a research place. The author also thanked the entire academic community of Natural Science Education program, Research And Community Service Directorate of Universitas Muhammadiyah Sidoarjo who has provided internal research grant assistance to develop the work of lecturers in the field of research and community service.

\section{REFERENCES}

Aninda, A., Permanasari, A., Ardianto, D., \& Kab Bogor, C. (2020). Implementasi pembelajaran berbasis proyek pada materi pencemaran lingkungan untuk meningkatkan literasi stem siswa sma. Journal of science education and practice, 3(2), 1-16. https://doi.org/10.33751/JSEP.V3I2.1719

Arini, W., \& Lovisia, E. (2019). Respon siswa terhadap media pembelajaran alat pirolisis sampah plastik berbasis lingkungan di smp kabupaten musi rawas. THABIEA : JOURNAL OF NATURAL SCIENCE TEACHING, 2(2), 95-104. https://doi.org/10.21043/THABIEA.V2I2.5950

Eka Priyani, N., Nawawi, dan, Negeri, S., Sintang, K., \& Kalimantan Barat, P. (2020). Pembelajaran ipa berbasis ethno-stem berbantu mikroskop digital untuk meningkatkan keterampilan proses sains di sekolah perbatasan. WASIS : Jurnal Ilmiah Pendidikan, 1(2), 99-104. https://doi.org/10.24176/WASIS.V1I2.5435

Faradisya Ekapti, R. (2016). Respon siswa dan guru dalam pembelajaran ipa terpadu konsep tekanan melalui problem based learning. Jurnal Pena Sains, 3(2). 
Fraenkel, J. R., Wallen, N. E., \& Hyun, H. H. (2012). How to design and evaluate research in education (8th ed). McGraw-Hill Humanities/Social Sciences/Languages.

Harahap, N., Antara Motivasi, H., \& STKIP Bina Bangsa Getsempena Banda Aceh, D. (2014). Hubungan antara motivasi dan aktivitas belajar siswa terhadap hasil belajar kognitif siswa dengan penerapan model pembelajaran kooperatif tipe student teams achievement division pada konsep ekosistem. Visipena, 5(1), 35-46. https://doi.org/10.46244/VISIPENA.V5I1.221

Hari, M., Program, Y., Pendidikan, S., Stkip, M., \& Lhokseumawe, B. P. (2018). Meningkatkan Aktivitas dan Hasil Belajar Matematika Melalui Strategi Pembelajaran TAPPS Berbasis Pendekatan (STEM). Jurnal Pendidikan Matematika:Judika Education, 1(2), 117-125. https://doi.org/10.31539/JUDIKA.V1I2.373

Herak, R. (2021). Peningkatan Hasil Belajar IPA Peserta Didik Kelas VIII Materi Sistem Ekskresi melalui Pengaruh Model STEM. Jurnal Studi Guru Dan Pembelajaran, 4(1), 127-134. https://doi.org/10.30605/JSGP.4.1.2021.516

Hermawan, M. A., Marwoto, P., Mindyarto, B., Negeri Semarang, U., \& Kelud Raya Sampangan, J. (2021). Analisis Respon Siswa Terhadap Pengembangan Media Pembelajaran Videoscribe Berpendekatan STEM Materi Termodinamika. Jurnal $\begin{array}{llll}\text { Penelitian Pembelajaran } & \text { Fisika, }\end{array}$ https://doi.org/10.26877/JP2F.V12I2.8067

Humairah Amir, R., \& Yuliana Purwanti, R. (2021). Efektivitas model pembelajaran steam (science, technology, engineering, art, and mathematics) pada siswa kelas iv sd. JKPD (Jurnal Kajian Pendidikan Dasar), 6(1), 1-13. https://doi.org/10.26618/JKPD.V6I1.4166

Muchtadi, M., Hartono, H., \& Oktaviana, D. (2017). Hubungan Aktivitas dan Respon terhadap Hasil Belajar Program Linier Setelah Diterapkan Pembelajaran Genius Learning pada Program Studi Pendidikan Matematika. Edu Sains: Jurnal Pendidikan Sains Dan Matematika, 5(1), 45-55. https://doi.org/10.23971/EDS.V5I1.668

Mudjiono, D. (2013). Belajar dan Pembelajaran (Revisi). PT Rineka Cipta.

Mulyasa, E. (2012). Kurikulum Tingkat Satuan Pendidikan (Revisi). PT Remaja Rosdakarya.

Muthmainnah, M., Johar, R., \& Anwar, A. (2019). Kemampuan Siswa SMP Membat Denah melalui Pendekatan Science, Technology, Engineering, Mathematics (STEM) Pada Materi Perbandingan. Jurnal Ilmiah Mahasiswa Pendidikan Matematika, 4(1).

Parasamya, C. E., Wahyuni, A., \& Hamid, A. (2017). Upaya peningkatan hasil belajar fisika siswa melalui penerapan model pembelajaran problem based learning (pbl). Jurnal Ilmiah Mahasiswa Pendidikan Fisika, 2(1), 42-49.

Purwanto, N. (2014). Psikologi Pendidikan (Revisi). PT Remaja Rosdakarya.

Rahmalia, R. (2021). Hubungan antara respon siswa terhadap bimbingan agama orang tua di rumah dengan hasil belajar kognitif pendidikan agama Islam siswa: Penelitian pada siswa kelas VIII SMP Negeri 1 Pangalengan.

Rakhma Pradani, D., Jurusan Fisika, W., \& Matematika dan Ilmu Pengetahuan Alam, F. (2018). Analisis Aktivitas Siswa dan Guru dalam Pembelajaran IPA Terpadu Kurikulum 2013 di SMP. UPEJ Unnes Physics Education Journal, 7(1), 57-66. https://doi.org/10.15294/UPEJ.V7I1.22476

Raudhatul Fadhilah, F., Ahmad Yani No, J., (2018). HUBUNGAN ANTARA AKTIVITAS BELAJAR SISWA DAN HASIL BELAJAR PADA MATA PELAJARAN KIMIA KELAS $X$ SMA NEGERI 5 PONTIANAK. Jurnal Ilmiah Ar-Razi, 6(1). https://doi.org/10.29406/ARZ.V6I1.939

Reffiane, F., Sudarmin, Wiyanto, \& Saptono, S. (2021). The instrument analysis of students' problem-solving ability on hybrid learning model using ETNO-STEM Approach through Quest Program in COVID-19 Pandemic. Pegem Journal of Education and Instruction, 11(4), 1-8. https://doi.org/10.47750/PEGEGOG.11.04.01 
Rozi, F., \& Hanum, C. B. (2019). Pembelajaran ipa sd berbasis hots (higher order thinking skills) menjawab tuntutan pembelajaran di abad 21. SEMINAR NASIONAL PGSD UNIMED, 2(1), 246-311.

Sartika, S. B. (2017). Pengembangan Perangkat Pembelajaran IPABerorientasi Model Pembelajaranyang Mengajarkan Keterampilan Berpikir Analisis Siswa SMP.

Sartika, S. B., Efendi, N., \& Rocmah, L. I. (2020). Keterampilan Berpikir Analisis Calon Guru IPA melalui Model 4A (Analisis Fenomena, Analisis Informasi, Analisis Data, Analisis Temuan). JURNAL PENDIDIKAN SAINS (JPS), 8(2), 165-170. https://doi.org/10.26714/JPS.8.2.2020.165-170

Slameto. (2010). Faktor-faktor yang Mempengaruhi Hasil Belajar (Revisi). PT Rineka Cipta.

Sumantri, B. A. (2019). Pengembangan kurikulum di indonesia menghadapi tuntutan kompetensi abad 21. At-Ta'lim : Media Informasi Pendidikan Islam, 18(1), 27-50. https://doi.org/10.29300/ATTALIM.V18I1.1614

Sumarni, W., \& Kadarwati, S. (2020). Ethno-Stem Project-Based Learning: Its Impact to Critical and Creative Thinking Skills. Jurnal Pendidikan IPA Indonesia, 9(1), 11-21. https://doi.org/10.15294/JPII.V9I1.21754

Susanto, A. (2014). Teori Belajar dan Pembelajaran di Sekolah Dasar. PT Fajar Interpratama Mandiri.

Wibowo, N. (2016). Upaya peningkatan keaktifan siswa melalui pembelajaran berdasarkan gaya belajar di smk negeri 1 saptosari. Elinvo (Electronics, Informatics, and Vocational Education), 1(2), 128-139. https://doi.org/10.21831/ELINVO.V1I2.10621 